\title{
Pengaruh Suplementasi L-Threonine dalam Pakan terhadap Kinerja Organ Dalam Ayam Broiler
}

\author{
Serfina Kolo ${ }^{\mathrm{a}}$, Charles V. Lisnahan ${ }^{\mathrm{b}}$, Oktovianus R. Nahak, T.B ${ }^{\mathrm{c}}$
}

${ }^{a}$ FakultasPertanian, Universitas Timor, Kefamenanu, TTU - NTT, 85613, Indonesia, email:serfinakolo13@gmail.com

${ }^{b}$ FakultasPertanian, Universitas Timor, Kefamenanu, TTU - NTT, 85613, Indonesia, email:charleslisnahan@yahoo.co.id

${ }^{c}$ FakultasPertanian, Universitas Timor, Kefamenanu, TTU - NTT, 85613, Indonesia, email:oktovianusrafael@yahoo.co.id

\section{Article Info}

\section{Article history:}

Received 24 Juni 2020

Received in revised form 14 September 2020 Accepted 07 Oktober 2020

$D O I$

https://doi.org/10.32938/ja.v5i4.1058

Keywords:

Ayam broiler

Pakan

L-threonine

Organ dalam

\section{Abstrak}

Penelitian ini telah dilaksanakan di Kelurahan Kefa Selatan, dan Laboratorium Fakultas Pertanian Universitas Timor, Kota Kefamenanu, Kabupaten Timor Tengah Utara selama 39 hari sejak Desember 2019 sampai Januari 2020. Tujuan penelitian untuk mengetahui pengaruh suplementasi $l$-threonine dalam pakan terhadap kinerja organ dalam ayam broiler. Penelitian ini menggunakan Day Old Chick broiler sebanyak 80 ekor. Metode penelitian yang digunakan adalah Rancangan Acak Lengkap (RAL) yang terdiri dari 4 perlakuan dan 4 ulangan. Setiap unit percobaan terdiri dari 5 ekor ayam broiler. Perlakuan yang diberikan adalah $\mathrm{T}_{0}$ : pakan kontrol, $\mathrm{T}_{1}:$ kontrol $+0,5 \%$ l-threonine, $\mathrm{T}_{2}:$ kontrol $+1,0 \%$ l-threonine, $\mathrm{T}_{3}:$ kontrol $+1,5 \%$ l-threonine. Variabel yang diamati adalah berat hati, berat limpa, berat pankreas, berat gizzard, berat usus halus dan panjang usus ayam broiler. Data yang diperoleh dianalisis dengan analisis sidik ragam dan dilanjutkan dengan uji Duncan. Hasil Analysis menunjukkan bahwa penambahan l-threonine berpengaruh nyata $(\mathrm{P}<0,05)$ terhadap berat gizzard, berat usus halus dan panjang usus. Kesimpulan suplementasi l-threonine $1,0 \%$ dalam pakan efektif meningkatkan berat gizzard, berat usus halus dan panjang usus ayam broiler.

\section{Pendahuluan}

Ayam broiler merupakan jenis ayam ras unggulan yang memiliki daya produktivitas tinggi, terutama dalam memproduksi daging (Santoso dan Sudaryani, 2011). Ayam broiler memiliki kelebihan dan kelemahan. Kelebihannya adalah mudah didapat, manajemen pemeliharaan yang lebih mudah, mudah di pasarkan dagingnya, ukuran badan besar, bentuk dada lebar, padat dan berisi, efesiensi pakan cukup tinggi, sebagian besar pakan diubah menjadi produk utama yaitu daging. Pertumbuhan ayam broiler sangat cepa dan dapat dipanen dalam waktu kurang dari 6 minggu. Sedangkan kelemahannya adalah memerlukan pemeliharaan yang serius dan lebih mudah terserang penyakit (Murtidjo, 2013).

Salah satu faktor penting dalam pemeliharaan ayam broiler yaitu pakan. Pakan adalah campuran dari beberapa zat makanan yang dibutuhkan untuk pertumbuhan, perkembangan dan produksi. Agar pertumbuhan dan produks ternak maksimal, jumlah dan kandungan zat-zat makanan ternak harus memadai (Suprijatna, 2010). Untuk memenuhi kebutuhan ternak maka ditambahkan asam amino kedalam pakan.

Salah satu asam amino yang dicampur dalam pakan adalah l-threonine. L-threonine merupakan asam amino ketiga yang paling membatasi dalam diet broiler, terutama dalam diet rendah protein mentah. L-threonine terlibat dalam proses metabolisme penting seperti pembentukan asam urat dan sintesis protein. Alasan l-threonine ditambahkan dalam pakan karena l-threonine tidak dapat disintesa oleh tubuh ternak ayam broiler, sehingga ditambahkan kedalam makanan unggas agar benar-benar cocok dengan keseimbangan asam amino. Ada banyak laporan tentang persyaratan l-threonine unggas (Rosa et al., 2001; Shan et al., 2003; Ahmadi dan Golian, 2010), tetapi lebih sedikit informas yang tersedia tentang efek diet l-threonine pada kinerja organ pencernaan. Tujuan penelitian ini untuk mengetahui pengaruh suplementasi l-threonine terhadap kinerja organ dalam ayam broiler.

\section{Metode}

\subsection{Waktu dan Tempat}

Penelitian ini telah dilaksanakan di Kampung Bima, Kelurahan Kefa Selatan dan Laboratorium Fakultas Pertanian Universitas Timor, Kelurahan Sasi, Kecamatan Kota Kefamenanu, Kabupaten Timor Tengah Utara, Propinsi Nusa Tenggara Timur. Penelitian berlangsung selama 5 minggu dimulai pada tanggal 21 Desember 2019 sampai tanggal 31 Januari 2020.

\subsection{Materi Penelitian}

Materi penelitian adalah ayam broiler berumur 1 hari atau Day Old Chick (DOC) Strain CP 707 sebanyak 80 ekor, pakan komersial produksi PT. Wonokoyo Jaya, dan l-threonine. Pakan dan air minum diberian ad libitum. Kandang yang digunakan dalam penelitian ini adalah kandang litter dibuat dalam 16 petak, tiap petak ukuranya tinggi $70 \mathrm{~cm}$ dan lebar $85 \mathrm{~cm}$. Ayam broiler dibagi dalam 16 unit kandang, masing-masing unit 5 ekor.

Tabel 1. Komposisi nutrien pakan $\mathrm{BR}_{1}$ dan $\mathrm{BR}_{2}$

\begin{tabular}{lcc}
\multicolumn{3}{l}{ Tabel 1. Komposisi nutrien pakan $\mathrm{BR}_{1}$ dan $\mathrm{BR}_{2}$} \\
\hline Nutrien & $\mathrm{BR}_{\mathrm{I}}$ & $\mathrm{BR}_{2}$ \\
\hline Protein Kasar (\%) & $20,0-22,0$ & $18,0-20,0$ \\
Lemak Kasar (\%) & $5,0-7,0$ & $5,0-7,0$ \\
Serat Kasar (\%) & $3,0-5,0$ & $3,0-5,0$ \\
Abu (\%) & $5,0-7,0$ & $5,0-7,0$ \\
Ca (\%) & $0,9-1,1$ & $0,9-1,1$ \\
Phosphor(\%) & $0,6-0,8$ & $0,6-0,8$ \\
ME (kkal) & $2900-3100$ & $3000-3200$ \\
\hline
\end{tabular}

Data yang diperoleh dianalisis dengan menggunakan analisis sidik ragam (Anova) sesuai dengan Rancangan Acak Lengkap (RAL) dan dilanjutkan dengan uji jarak berganda Duncan untuk melihat perbedaan antara perlakuan. Analisis data menggunakan software SPSS versi 20.

\section{Hasil dan Pembahasan}

\subsection{Berat Hati dan Persentase Berat Hati Ayam Broiler}

Rata-rata berat hati dan persentase berat hati ayam broiler disajikan pada Tabel 2. Rata-rata berat hati tertinggi pada perlakuan $T_{2}$ yaitu $44,36 \pm 7,27$ g/ekor atau 2,14 $\pm 0,35 \%$ /ekor. Selanjutnya diikuti perlakuan $\mathrm{T}_{3}(40,56 \pm 3,4$ g/ekor atau $2,06 \pm 0,15 \%$ /ekor), $\mathrm{T}_{1}(39,83 \pm 6,59 \mathrm{~g} / \mathrm{ekor}$ atau $2,59 \pm 0,83 \%$ /ekor $)$ dan terendah pada perlakuan $\mathrm{T}_{0}(37,96 \pm 1,06 \mathrm{~g} /$ ekor atau $2,32 \pm 0,45 \% /$ ekor $)$ Analisis sidik ragam menunjukkan bahwa perlakuan berpengaruh tidak nyata 
terhadap berat hati dan persentase berat hati ayam broiler. Hati adalah tempat untuk emulsi lemak dan tautan kantong empedu. Dalam pencernaan, hati penting untuk menghasilkan getah empedu yang disalurkan ke duodenum (NRC, 2000; Scanes et al., 2004). Pakan yang memasuki duodenum menstimulasi kantong empedu untuk menyusut dan mengeluarkan getah empedu ke dalam duodenum, yang dapat membantu menyerap lemak oleh usus kecil (Pesti et al., 2005). Berat rata-rata hati dan empedu ayam asli adalah $5,56 \%$ dari berat badan (Lisnahan et al., 2017). L-threonine berkontribusi pada pembentukan tulang, metabolisme lemak dan fungsi pencernaan; mengontrol kesehatan dan sistem kekebalan tubuh, hati dan saraf dan mempertahankan protein tubuh (Qaisrani et al., 2018). Menurut Grist (2006) hati berfungsi memproduksi dan sekresi empedu, menghasilkan larutan asam berisi dua garam empedu bilirubin dan biliverdin, enzim amilase, filtrasi zat-zat toksit, sintesis kimia, dan thermoregulasi. Pada penelitian ini, hati tidak mengalami tandatanda keracunan zat antinutrien akibat penambahan l-threonine sampai level $1,5 \%$ dalam pakan. McLelland (1990) menyatakan bahwa jika terjadi keracunan di hati maka warnanya akan berubah menjadi kuning dan terjadi pembesaran atau pembengkakan.

\subsection{Berat Limpa dan Persentase Berat Limpa Ayam Broiler}

Rata-rata berat limpa dan persentase berat limpa ayam broiler tersaji pada Tabel 2. Rata-rata berat limpa tertinggi terdapat pada perlakuan $\mathrm{T}_{3}$ yaitu $2,75 \pm 0,87 \mathrm{~g} /$ ekor atau $0,14 \pm 0,05 \%$ /ekor. Diikuti perlakuan $\mathrm{T}_{0}(2,56 \pm 0,61$

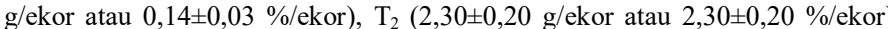
dan terendah pada perlakuan $\mathrm{T}_{1}(2,13 \pm 0,83$ g/ekor atau $0,14 \pm 0,03 \%$ /ekor $)$. Analisis sidik ragam menunjukkan bahwa perlakuan berpengaruh tidak nyata terhadap berat limpa dan persentase berat limpa ayam broiler. Suplementasi $l$ threonine dalam pakan tidak berpengaruh terhadap berat limpa dan persentase berat limpa ayam broiler. Hal ini mengakibatkan $l$-threonine tidak memberikan respon terbaik terhadap berat pankreas dan persentase berat pankeas. Rataan persentase bobot limpa ayam pedaging 0,10-0,18 (Mulyadi, 2001). Limpa berperan dalam sirkulasi darah yaitu tempat penampung darah (Frandson, 1992; Aqsa et al., 2016). Dijelaskan juga oleh Ressang (1984) dan Aqsa et al. (2016) bahwa fungsi limpa yaitu untuk menyimpan darah bersama hati dan sum-sum tulang belakang dan berperan dalam menghilangkan eritrosit-eritrosit tua. Pada metabolisme nitrogen, limpa turut serta dalam pembentukan asam urat dan membentuk limfosit yang berhubungan dengan pembentukan antibodi.

Tabel 2. Rata-rata kinerja organ dalam ayam broiler

\begin{tabular}{lcccc}
\hline \multirow{2}{*}{ Parameter } & \multicolumn{4}{c}{ Perlakuan } \\
\cline { 2 - 5 } & $\mathrm{T}_{0}$ & $\mathrm{~T}_{1}$ & $\mathrm{~T}_{2}$ & $\mathrm{~T}_{3}$ \\
\hline $\begin{array}{l}\text { Berat hati } \\
\text { g/ekor) }\end{array}$ & $37,96 \pm 1,06$ & $39,83 \pm 6,59$ & $44,36 \pm 7,27$ & $40,56 \pm 3,4$ \\
$\begin{array}{l}\text { Persentase } \\
\text { berat hati } \\
(\% / \text { ekor) }\end{array}$ & $2,32 \pm 0,45$ & $2,59 \pm 0,83$ & $2,14 \pm 0,35$ & $2,06 \pm 0,15$ \\
$\begin{array}{l}\text { Berat limpa } \\
\text { (g/ekor) }\end{array}$ & $2,56 \pm 0,61$ & $2,13 \pm 0,83$ & $2,30 \pm 0,20$ & $2,75 \pm 0,87$ \\
$\begin{array}{l}\text { Persentase } \\
\text { berat limpa } \\
\text { (\%/ekor) }\end{array}$ & $0,14 \pm 0,03$ & $0,11 \pm 0,04$ & $0,11 \pm 0,02$ & $0,14 \pm 0,05$ \\
$\begin{array}{l}\text { Berat } \\
\text { pankreas }\end{array}$ & $3,81 \pm 0,47$ & $3,89 \pm 0,78$ & $3,89 \pm 0,82$ & $3,22 \pm 1,30$
\end{tabular}

(g/ekor)

Persentase

berat

pankreas

$0,21 \pm 0,03 \quad 0,21 \pm 0,04 \quad 0,19 \pm 0,04$

$0,16 \pm 0,07$

(\%/ekor)

Berat

gizzard

$28.52 \pm 1.93^{\mathrm{d}} \quad 30.83 \pm 1.53^{\mathrm{c}} \quad 36.82 \pm 0.63^{\mathrm{a}}$

$33.81 \pm 1.45^{\mathrm{b}}$

(g/ekor)

Persentase

(\%/kor)

Berat usus

halus

$34,95 \pm 1,75^{\mathrm{b}} \quad 45,19 \pm 7,52^{\mathrm{a}} \quad 44,07 \pm 1,58^{\mathrm{a}} \quad 40,27 \pm 3,84^{\mathrm{ab}}$

(g/ekor)

Persentase

berat usus

halus

$$
1,95 \pm 0,10^{\mathrm{b}} \quad 2,43 \pm 0,41^{\mathrm{a}} \quad 2,12 \pm 0,02^{\mathrm{ab}}
$$

$2,04 \pm 0,17^{\mathrm{b}}$

(\%/ekor)

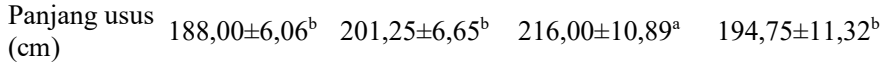

$188,00 \pm 6,06^{\mathrm{b}} \quad 201,25 \pm 6,65^{\mathrm{b}} \quad 216,00 \pm 10,89^{\mathrm{a}} \quad 194,75 \pm 11,32^{\mathrm{b}}$
b,c,d superskrip pada baris rata-rata menunjukkan perbedaan $(P<0,05)$

\subsection{Berat Pankreas dan Persentase Berat Pankreas Ayam Broiler}

Rata-rata berat pankreas dan persentase berat pankreas ayam broiler disajikan pada Tabel 2. Rata-rata berat hati dan persentase berat hati tertinggi pada perlakuan $\mathrm{T}_{2}(3,89 \pm 0,82 \mathrm{~g} /$ ekor atau $0,19 \pm 0,04 \%$ /ekor $), \mathrm{T}_{1} \quad(3,89 \pm 0,78$ g/ekor atau $0,21 \pm 0,04 \%$ /ekor), $\mathrm{T}_{0}(3,81 \pm 0,47 \mathrm{~g}$ /ekor atau $0,21 \pm 0,03 \%$ /ekor) dan terendah pada perlakuan $\mathrm{T}_{3}(3,22 \pm 1,30 \mathrm{~g} / \mathrm{ekor}$ atau $0,16 \pm 0,07 \%$ /ekor $)$. Analisis sidik ragam menunjukkan bahwa perlakuan berpengaruh tidak nyata terhadap berat pankreas dan persentase berat pankreas ayam broiler. Proses pencernaan utama pada unggas berlangsung secara enzimatik. Pankreas merupakan organ utama yang mensekresikan entri pankreas yaitu amylase, tripsin dan lipase yang berfungsi dalam pencernaan pati, lemak, dan protein di dalam usus. Selain mensekresikan getah pankreas, juga berfungsi mensekresikan hormon insulin (Aqsa et al., 2016). Sebelumnya dijelaskan Yuwanta (2004) bahwa pankreas memiliki dua fungsi utama yang berhubungan dengan penggunaan pakan, yaitu eksokrin dan pengaturan energi pakan yaitu fungsi endokrin. Sebagai fungsi eksokrin, pankreas mensuplai enzim amylase untuk mencerna pati (karbohidrat), tripsin untuk mencerna protein dan lipase untuk mencerna lemak pad bagian $\alpha$-pankreas. Amilase, tripsin dan lipase yang dihasilkan pankeas dibawa kedalam duodenum, jejunum dan ileum sebagai tempat utama pencernaan secara enzimatik pada unggas. Pankreas terletak antara lekukan duodenum (duodenum lup) yang merupakan bagian awal usus halus (Rahayu et al., 2011; Aqsa et al., 2016). Sementara fungsi pankreas sebagai endokrin adalah menghasilkan hormone insulin pada bagian beta $\beta$ pankreas. Fungsi hormon ini sebagai pengatur nutrien berupa energi untuk diserap dalam tubuh dan menetralkan glukosa darah. Faktor yang mempengaruhi persentase berat pankreas yaitu faktor genetik, tingkah laku dan lingkungan (Yuwanta, 2004; Aqsa et al., 2016). Hal ini disebabkan karena perlakuan terhadap variabel penelitian jika diberikan l-threonine 1,0\% maka terjadi peningkatan berdasarkan penelitian terhadap variabel $T_{2}$ dengan persentase 3,89\%. Apabila ditingkatkan level l-threonine 1,5\% maka berat pankreas dan persentase berat pankreas cenderung menurun. Hal ini disebabkan oleh keseimbangan suplementasi l-threonine yang diberikan bila melebihi maka akan mengakibatkan berat dan persentase pankreas menurun.

\subsection{Berat Gizzard dan Persentase Berat Gizzard Ayam Broiler}

Rata-rata berat gizzard dan persentase berat gizzard ayam broiler disajikan pada Tabel 2. Rata-rata berat gizzard dan persentase tertinggi pada perlakuan $\mathrm{T}_{2}$ yaitu $36,82 \pm 0,63 \mathrm{~g}$ /ekor atau $1,77 \pm 0,05 \%$ /ekor. Selanjutnya diikuti oleh $\mathrm{T}_{3}(33,8125 \pm 1,45 \mathrm{~g} /$ ekor atau $1,72 \pm 0,08 \%$ /ekor $), \mathrm{T}_{1}(30,83 \pm 1,53$ g/ekor atau $1,66 \pm 0,08 \%$ /ekor) dan terendah pada perlakuan $\mathrm{T}_{0}(28,52 \pm 1,93$ g/ekor atau $1,59 \pm 0,10 \%$ /ekor). Analisis sidik ragam menunjukkan bahwa perlakuan berpengaruh nyata pada berat gizzard dan persentase berat gizzard ayam broiler. Uji Duncan menunjukkan bahwa perlakuan $T_{2}$ mempunyai berat gizzard berbeda dari $T_{3}, T_{1}$ dan $T_{0}$ sedangkan perlakuan $T_{3}$ berbeda dari $T_{1}$ dan $\mathrm{T}_{0}$ dan perlakuan $\mathrm{T}_{1}$ berbeda dari perlakuan $\mathrm{T}_{0}$. Suplementasi l-threonine $0,5 \%$ dalam pakan $\left(\mathrm{T}_{1}\right)$, meningkatkan $8,09 \%$ berat gizzard ayam broiler dibandingkan dengan pakan tanpa suplementasi l-threonine $\left(\mathrm{T}_{0}\right)$. Apabila ditingkatkan menjadi $1,0 \%\left(\mathrm{~T}_{2}\right)$ berat gizzard meningkat sebesar $9,69 \%$ dibandingkan $\mathrm{T}_{1}$. Pada $\mathrm{T} 3$ dengan ditingkatkannya level l-threonine menjad $1,5 \%$ pertambahan berat gizzard cenderung menurun menjadi $8,90 \%$ dibandingkan dengan perlakuan $\mathrm{T}_{2}$. Semakin tinggi level l-threonine dalam pakan cenderung meningkatkan berat gizzard ayam broiler. Namun pada suplementasi l-threonine $1,5 \%$ berat gizzard cenderung menurun. Hal ini disebabkan oleh kandungan nutrien yang semakin berimbang pada pakan yang disuplementasi l-threonine. Pakan yang semakin berimbang nutriennya menyebabkan konsumsi pakan dan pertumbuhan lebih baik termasuk pertumbuhan jaringan tubuh seperti gizzard. Hal ini dikuatkan oleh Faishal et al. (2013) bahwa peningkatan konsumsi pakan juga dapat mengakibatkan urat daging gizzard akan lebih tebal sehingga memperbesar ukurannya.

Rata-rata persentase berat gizzard unggas yaitu 1,6-2,3\% dari bobot potong (Sturkie, 2000; Simamora, 2011). Gizzard adalah lambung mekanis yang terletak antara proventrikulus dan duodenum. Pakan yang dikonsumsi dan cairan pencernaan dari kelenjar ludah dan proventriculus masuk ke dalam gizzard yang selanjutnya digiling, dicampur dan dihaluskan (Svihus, 2014). Berat gizzard berkorelasi dengan berat tubuh ayam, semakin besar dan berat tubuh ayam, semakin besar gizzard, semakin besar luas permukaan kaolin untuk menggiling pakan. Suplementasi l-threonine berdampak pada pertumbuhan yang lebih baik, termasuk gizzard.

\subsection{Berat Usus Halus dan Persentase Berat Usus Halus}

Rata-rata berat usus halus dan persentase berat usus halus ayam broiler disajikan pada Tabel 2. Rata-rata berat usus halus tertinggi terdapat pada perlakuan $\mathrm{T}_{1}$ yaitu $34,95 \pm 1,75 \mathrm{~g} /$ ekor atau $2,43 \pm 0,41 \%$ /ekor, diikuti perlakuan $\mathrm{T}_{2}(44,07 \pm 1,58 \mathrm{~g} /$ ekor atau $2,12 \pm 0,02 \%$ /ekor $), \mathrm{T}_{3}(40,27 \pm 3,84 \mathrm{~g} / \mathrm{ekor}$ atau $2,04 \pm 0,17 \%$ /ekor) dan terendah pada perlakuan $\mathrm{T}_{0}(34,95 \pm 1,75 \mathrm{~g} /$ ekor atau $1,95 \pm 0,10 \%$ /ekor). Analisis sidik ragam menunjukkan bahwa perlakuan berpengaruh nyata pada berat usus halus dan persentase berat usus halus ayam broiler $(\mathrm{P}<0,05)$. Uji duncan menunjukkan bahwa berat usus halus dan persentase berat usus halus pada perlakuan $T_{1}, T_{2}$ dan $T_{3}$ berbeda dari perlakuan $\mathrm{T}_{0}$. Suplementasi l-threonine $0,5 \%\left(\mathrm{~T}_{1}\right)$ atau $1,0 \%\left(\mathrm{~T}_{2}\right)$ dalam pakan meningkatkan $29,30 \%$ atau $26,09 \%$ berat usus halus ayam broiler dibandingkan dengan perlakuan $\mathrm{T}_{0}$. Apabila suplementasinya l-threonine ditingkatkan menjadi $1,5 \%\left(\mathrm{~T}_{3}\right)$, berat usus halus cenderung menurun sebesar $8,62 \%$ dibandingkan dengan perlakuan $\mathrm{T}_{2}$. Pakan yang disuplementasi l-threonine menyebabkan nutrien yang lebih seimbang sehingga konsumsi pakan dan pertumbuhan semakin meningkat. Akibatnya pertumbuhan organ pencernaan seperti usus juga meningkat. Namun, apabila suplementasi l-threonine ditingkatkan sebesar $1,5 \%$ berat usus halus semakin kecil. Rofiq (2003) menyatakan bahwa kecernaan bahan pakan dipengaruhi oleh faktor lain pada pakan yaitu antinutrien yang mempengaruhi pertumbuhan struktur vili. Rata- 
rata persentase berat usus halus 2,43-3,05\% (Tambunan, 2007) dari berat potong. Suplementasi l-threonine dalam pakan meningkatkan persentase berat usus yang normal.Usus adalah bagian utama dari pencernaan pakan dan penyerapan nutrien (Svihus, 2014). Semakin panjang, besar dan berat usus, semakin banyak pakan untuk dicerna dan diserap. Asam amino yang seimbang, terutama asam amino esensial, membangun jaringan tubuh yang lebih baik dan mendukung pertumbuhan dan usus ayam yang lebih baik. Fungsi asam amino $l$ threonine adalah untuk mengatur keseimbangan protein dan asam amino, mempertahankan fungsi usus dan meningkatkan respon imun (Chen et al., 2017; Qaisrani et al., 2018).

\subsection{Panjang Usus}

Rata-rata panjang usus disajikan pada Tabel 2. Rata-rata panjang usus tertinggi pada perlakuan $\mathrm{T}_{2}(216,00 \pm 10,89 \mathrm{~cm} / \mathrm{ekor}), \mathrm{T}_{1}(201,25 \pm 6,65 \mathrm{~cm} / \mathrm{ekor})$, $\mathrm{T}_{3}(194,75 \pm 11,32 \mathrm{~cm} / \mathrm{ekor})$ dan $\mathrm{T}_{0}(188,00 \pm 6,06 \mathrm{~cm} / \mathrm{ekor})$. Analisis sidik ragam menunjukkan bahwa perlakuan berpengaruh nyata pada panjang usus ayam broiler $(\mathrm{P}<0,05)$. Uji duncan menunjukkan bahwa panjang usus pada perlakuan $\mathrm{T}_{2}$ berbeda dari perlakuan $\mathrm{T}_{0}, \mathrm{~T}_{1}$ dan $\mathrm{T}_{3}$. Suplementasi l-threonine $0,5 \%$ dalam pakan $\left(\mathrm{T}_{1}\right)$, belum meningkatkan panjang usus ayam broiler dibandingkan dengan pakan tanpa suplementasi l-threonine $\left(\mathrm{T}_{0}\right)$. Apabila level l-threonine ditingkatkan menjadi $1,0 \%\left(\mathrm{~T}_{2}\right)$ panjang usus ayam broiler meningkatkan $7,33 \%$ dibandingakn dengan perlakuan $\mathrm{T}_{0}$ atau $14,89 \%$ di bandingkan dengan perlakuan $\mathrm{T}_{1}$. Pada $\mathrm{T}_{3}$ dengan ditingkatkannya level level l-threonine menjadi $1,5 \%$, panjang usus cenderung menurun menjadi $9,84 \%$ dibandingkan dengan $\mathrm{T}_{2}$. Hal ini berarti panjang usus pada suplementasi $1,0 \%$ l-threonine lebih baik dari perlakuan lainnya.

Rata-rata persentase panjang usus normal $150 \mathrm{~cm}$ (Suprijatna et al. 2008; Warni, 2018). Menurut Amrullah (2003) dan Siregar (2011) bahwa panjang usus diikuti dengan jumlah vili usus dan kemampuan sekresi akan meningkatkan kecernaan dan absorbsi nutrien kedalam tubuh. Peningkatan kadar serat kasar dalam pakan cenderung akan memperpanjang usus yaitu semakin tinggi serat kasar dalam pakan maka semakin lambat laju pencernaan dan penyerapan nutrien. Luas permukaan usus akan meningkat seiring dengan bertambahnya jumlah vili usus yang berfungsi untuk penyerapan zat-zat makanan (Frandson, 1992; Aqsa et al., 2016). L-threonine berkontribusi pada keseimbangan protein dan asam amino dan juga membantu menjaga fungsi usus dan meningkatkan respons imun.

\section{Simpulan}

Berdasarkan hasil dan pembahasan dapat disimpulkan bahwa suplementasi $1,0 \%\left(\mathrm{~T}_{2}\right)$ l-threonine dalam pakan meningkatkan berat gizzard berat usus halus dan panjang usus ayam broiler.

\section{Pustaka}

Ahmadi, H. \&Golian, A., 2010. The integration of broiler chicken threonine responses data into neural network models. Poult. Sci, $89: 2535-2541$.

Amrullah, I. K. 2003. Nutrisi Ayam Broiler. Cetakan Ke-2. Lembaga Satu Gunung Budi, Bogor.

Aqsa, A. D., K. Kiramang, dan M. N. Hidayat. 2016. Profil organ dalam ayam pedaging (broiler) yang diberi tepung daun sirih (piper betle linn) sebagai imbuhan pakan. Jurnal Ilmu dan industry peternakan, 3(1): 148159.

Chen, Y. P., Y. F. Cheng, X. H. Li, W. L. Yang, C. Wen, S. Zhuang and Y. M. Zhou. 2017. Effects Of Threonine Supplementation On The Growth Performance, Immunity, Oxidative Status, Intestinal Integrity And Barrier Function Of Broilers At The Early Age. Poultry Science, 96 405-413.

Faishal, I. H. and E. Sudjarwo. 2013. Effect of addition mangosteen peel powder (Garcinia mangostana L.) to feed on carcas and internal organs mojosari drake. Jurnal Brawijaya, 5(1) : 1-10.

Frandson, R. D. 1992. Anatomi dan Fisiologi Ternak. Edisi ke-4. Gadjah Mada University Press. Yogyakarta.

Grist, A. 2006. Poultry Inspection-Anatomy Phsiology and Disease conditions. 2nd Ed. Nottingham, United Kingdom: Nottingham Univ Press.

Lisnahan, C. V., Wihandoyo, Zuprizal and S. Harimurti. 2017. Effect Of Addition Of Methionine And Lysine Into Diets Based On Cafeteria Standards On The Growth Performance Of Native Chickens At Starter Phase. International Journal of Poultry Science, 16 (12) : 506-510.

McLelland, J. 1990. A Colour Atlas of Avian Anatomy. Wolfe Publishing Ltd., London.

Mulyadi, E. 2001. Pengaruh Pemberian Berbagai Level Cacing Tanah Segar (Lumbricus rubellus) dalam Pakan terhadap Persentase Bobot Karkas dan Organ dalam Broiler. Skripsi. Jurusan Peternakan, Fakultas Pertanian.

Murtidjo, B.A. 2013. Pedoman Meramu Pakan Unggas. Penerbit Yayasan Kanisius, Yogyakarta

National Research Council. 2000. Nutrient Requairement of Poultry Eight Revised Ed. National Academy Press, Washington, DC 155 pages.

Pesti, G. M., R. I. Bakalli, J. P. Driver, A. Atencio and E. H. Foster. 2005. Poultry Nutrition and Feeding. The University of Georgia. Department of Poultry Science, Trafford Publishing, Athens.
Qaisrani, S. N., I. Ahmed, F. Azam, F. Bibi, Saima, T. N. Pasha and F. Azam. 2018. Threonine in broiler diets: an updated review. Annal Animal Science, 18 (3) : 659-674.

Rahayu, I., T. Sudaryani, dan H. Santosa. 2011. Panduan Lengkap Ayam. Penebar Swadaya. Jakarta.

Ressang. 1984. Patologi Khusus Veteriner. Edisi ke-2. N.V. Percetakan Bali. Denpasar.

Rofiq, M. N. 2003. Pengaruh pakan berbahan baku lokal terhadap performa vili usus ayam broiler. Jurnal Sains dan Teknologi Indonesia, 5 (5) : 190194.

Rosa, A.P., Pesti, G.M., Edwards, H.M. \&Bakalli, R.I., 2001. Threonine requirements of different broiler genotypes. Poult. Sci, 80 : 1710-1717.

Santoso, H dan T. Sudaryani. 2011. Pembesaran Ayam Pedaging Di Kandang Panggung Terbuka. Penebar Swadaya, Jakarta.

Scanes, C. G., G. Brant, and M. E. Esminger. 2004. Poultry science. $4^{\text {th }}$ edition. Person education Inc., New Jersey

Shan, A. S., K. G. Sterling, G. M. Pesti, R. I. Bakalli, G. P. Driver, and A. A. Tejedor. 2003. The sinfluence of temperature on the threonine and tryptophan requirements of young broiler chicks. Poult. Sci, 82 : 1154 1162 .

Simamora, N. 2011. Performa produksi dan karakteristik organ dalam ayam kampung umur 12-16 minggu yang diinfeksi cacing ascaridia galli dan suplementasi ekstrak daun jarak pagar (Jatropha curcas Linn). Skripsi. Fakultas Peternakan. Institute Pertanian Bogor. Bogor.

Siregar, D. Z. 2011. Persentase karkas dan pertumbuhan organ dalam ayam broiler pada frekuensi dan waktu pemberian pakan yang berbeda. Skripsi. Fakultas Peternakan. Institut Pertanian Bogor. Bogor.

Sturkie, P. D. 2000. Avian Psiology. Edisi ke-15. Spinger-Verlag, NewYork.

Suprijatna, E. 2010. Strategi Pengembangan Ayam Lokal berbasis Sumber Daya Lokal dan Berwawasan Lingkungan. Prosiding Seminar Nasional Unggas Lokal ke IV. hal. $55-79$.

Suprijatna, E., U. Atmomarsono, Kartasujadna. 2008. Ilmu Dasar Ternak Unggas. Penebar Swadaya. Jakarta.

Svihus, B. 2014. Function of The Digestive System. Journal Applied Poultry Research, 23 (2) : 306-314

Tambunan, I. R. 2007. Pengaruh Pemberian Tepung Kertas Koran pada Periode Grower Terhadap Persentase Karkas, Lemak Abdominal, Organ Dalam dan Saluran Pencernaan Ayam Broiler. Skripsi. Fakultas Peternakan, Institut Pertanian Bogor, Bogor.

Warni, I. S. 2018. Pengaruh pemberian air rebusan kunyit (curcuma domestica) terhadap total mikroba dan Escherichia coli serta bobot sekum ayam broiler. Skripsi. Fakultas Peternakan, Universitas Diponegoro. Semarang.

Yuwanta, T. 2004. Dasar Ternak Unggas. Kanisius. Yogyakarta. 